\title{
GONADOTROPHIC CONTROL OF TRITIATED THYMIDINE INCORPORATION IN THE GERMINAL CELLS OF THE RAT TESTIS
}

\author{
R. ORTAVANT, M. COUROT AND \\ M. T. HOCHEREAU-DE REVIERS \\ I.N.R.A., Laboratory of Reproductive Physiology, 37-Nouzilly, France
}

(Received 21st April 1972, accepted 6th Fuly 1972)

The gonadotrophic control of spermatogenesis varies with age. Thus, ovine FSH stimulates spermatogenesis in the hypophysectomized prepubertal rat more effectively than ovine LH whereas the opposite is found in the adult (Ortavant, Courot \& de Reviers, 1969; Courot, Ortavant \& de Reviers, 1971). Gonadotrophic hormones reduce the proportion of germinal cells which undergo degeneration. It was thought probable that this effect was the result of actions of these hormones on the metabolism of germinal cells. We have started to investigate this problem by studying the effects of FSH and LH on the synthesis of DNA by spermatogonia and primary spermatocytes in the rat. It has previously been shown that hypophysectomy reduces the intensity of $\left[{ }^{3} \mathrm{H}\right]$ thymidine-labelling of the DNA in these cells ( $\mathrm{R}$. Ortavant, unpublished data).

Six prepubertal and six adult Wistar rats were hypophysectomized and then treated subcutaneously with highly purified ovine FSH or LH: the adult rats received three injections, each containing $100 \mu \mathrm{g}$ FSH-GNRS-DE $58(\times 1.5 \mathrm{NIH}$ FSH-S1) or $100 \mu \mathrm{g}$ LH-GNRS-M2 ( $\times 1.4$ NIH LH-S1), at 12-hourly intervals starting 30 days after hypophysectomy; the prepubertal rats received $15 \mu$ g FSH-CNRS-M1 ( $\times 4$ NIH FSH-S1) or $20 \mu \mathrm{g} \mathrm{LH} \mathrm{CNRS-M1} \mathrm{(} \times 1.5 \mathrm{NIH} \mathrm{LH-s1)} \mathrm{twice} \mathrm{daily} \mathrm{for} 12$ days, starting immediately after hypophysectomy on the 27th day after birth. Previous experiments using these treatment schedules had demonstrated an effect of FSH on spermatogenesis in prepubertal rats and of $\mathbf{L H}$ in adults. All the rats were killed $12 \mathrm{hr}$ after the last injection of hormone, $1 \mathrm{hr}$ after intraperitoneal administration of $\left[{ }^{3} \mathrm{H}\right]$ thymidine $(1 \cdot 1 \mu \mathrm{Ci} / \mathrm{g}$ body weight, specific activity: $10 \mathrm{Ci} / \mathrm{mmol}$ ).

The testes were fixed in Bouin-Hollande solution and autoradiographs of 5- $\mu \mathrm{m}$ paraffin-wax sections were prepared with Ilford $\mathrm{K} 5$ emulsion. Photometric grain density measurements were made over type $A_{3}$ and $A_{4}$ spermatogonia (Glermont \& Bustos-Obregon, 1968) at stages 3 and 4 of the cycle of the seminiferous epithelium and over preleptotene and leptotene primary spermatocytes at stages 8 and 1 (Roosen-Runge \& Giesel, 1950). The grain density was measured over sixty nuclei of each type of cell in each animal and the median intensities of labelling were compared by the method of Lazar \& Gerard-Marchant (1965) after subtraction of the background level. 
No correction has been made for autoabsorption as there was little variation in the volumes of the nuclei studied. The results are given in arbitrary units which are proportional to the grain density.

The results given in Table 1 show that the intensity of labelling in the adult rats was much greater after LH treatment than after FSH treatment or in untreated hypophysectomized animals. In the prepubertal rats, on the other hand, FSH treatment markedly increased the uptake of $\left[{ }^{3} \mathrm{H}\right]$ thymidine into germinal cell nuclei whereas LH did not have this effect. Although the actual intensity of labelling was greater in the spermatogonia than in the spermatocytes, the gonadotrophin-induced increases in labelling intensity were larger in the spermatocytes.

TABLE 1

INTENSITY OF NUGLEAR LABELLING BY $\left[{ }^{3} \mathrm{H}\right]$ THYMIDINE IN THE GERMINAL GELLS OF RATS AFTER HYPOPHYSECTOMY AND GONADOTROPHIN TREATMENT

\begin{tabular}{l|c|c|c|c}
\hline & \multicolumn{3}{|c|}{ Prepubertal rats } & \multicolumn{2}{c}{ Adult rats } \\
\cline { 2 - 5 } & $\begin{array}{c}A_{3} \text { and } A_{4} \\
\text { spermatogonia }\end{array}$ & $\begin{array}{c}\text { Preleptotene and } \\
\text { leptotene I } \\
\text { spermatocytes }\end{array}$ & $\begin{array}{c}A_{3} \text { and } A_{4} \\
\text { spermatogonia }\end{array}$ & $\begin{array}{c}\text { Preleptotene and } \\
\text { leptotene } \\
\text { spermatocytes }\end{array}$ \\
\hline Hypophysectomy & $17 \cdot 0$ & $5 \cdot 0$ & $15 \cdot 0$ & $8 \cdot 0$ \\
Hypophysectomy + FsH & 21.0 & $14 \cdot 9$ & $15 \cdot 8$ & $9 \cdot 0$ \\
Hypophysectomy+ LH & $12 \cdot 5$ & 6.4 & 26.0 & $20 \cdot 8$ \\
\hline
\end{tabular}

Median labelling intensity per nucleus, expressed in arbitrary units which are proportional to grain density (Lazar \& Gerard-Marchant, 1965).

The gonadotrophin treatments are described in the text.

The variations with age in the effects of FSH and LH on thymidine incorporation parallel age differences in the effects of gonadotrophins on testicular weight (Ortavant et al., 1969) and in the histological appearance of the testis (Courot et al., 1971). In all animals, the intensity of labelling was greater in the spermatogonia than in the spermatocytes. This has been reported previously and may be related to the longer duration of the phase of DNA synthesis in the spermatocytes (Hilscher, 1964).

These findings raise the question of how gonadotrophins increase the rate of thymidine incorporation. The effect might be due to a change in the duration of DNA synthesis. This is thought to be unlikely because the proportion of labelled cells and the proportion of the cycle of the seminiferous epithelium in which labelled cells are observed are not affected by the endocrine environment (Desclin \& Ortavant, 1963; Clermont \& Harvey, 1965).

It is unlikely that gonadotrophins increase thymidine uptake by provoking a change in the quantity of DNA per nucleus (aneuploidy). Microphotometer measurements show no change in the DNA content of zygotene primary spermatocytes or of round spermatids after hypophysectomy (G. Esnault, personal communication). However, these measurements do not exclude the possibility that cells which have not completely doubled their DNA content might degenerate. Go, Vernon \& Fritz (1971) have reported that the total amount of $\left[{ }^{3} \mathrm{H}\right]$ thymidine incorporated into the DNA of a homogenous popula- 
tion of testicular cells declines rapidly after hypophysectomy whereas the level remains constant for considerably longer in cells from normal animals.

Gonadotrophins might affect the availability of thymidine by acting on enzyme systems responsible for DNA synthesis or by affecting access of the precursor to the site of synthesis. It has been shown that hypophysial extract causes changes in membrane potential in fish germinal cells (Smith, 1970), an effect which might be associated with increased transport of DNA precursor.

Previous workers have noted that the incorporation of thymidine varies with the physiological state of the testis (Hollinger \& Davis, 1969; Wiest \& Wrba, 1970; Go et al., 1971); the results appear to depend on the number of cells synthesizing DNA. The present experiments suggest that gonadotrophins control the DNA synthetic activity of the individual germ cells, but it is not known whether the gonadotrophins affect the germ cells directly or whether they have primary actions on the Leydig and supporting cells.

This work was supported by the French National Institute for Agronomic Research (I.N.R.A.). The gift of gonadotrophic hormones by the Centre National de la Recherche Scientifique (GNRS) (Dr Jutisz's laboratory) is gratefully acknowledged. The authors are indebted to Dr A. G. Davies for translating this note and to Madame Agnès Daveau for technical assistance.

\section{REFERENCES}

Clermont, Y. \& Bustos-Obregon, E. (1968) Re-examination of spermatogonial renewal in the rat by means of seminiferous tubules mounted in toto. Am. J. Anat. 122, 237.

Clemmont, Y. \& Harvey, S. C. (1965) Duration of the cycle of the seminiferous epithelium of normal, hypophysectomized and hypophysectomized-hormone treated albino rats. Endocrinology, 76, 80.

Courot, M., Ortavant, R. \& De Reviers, M. M. (1971) Variations du contrôle gonadotrope du testicule selon l'âge des animaux. Exper. anim. 4, 201.

Desclin, J. \& Ortavant, R. (1963) Influence des hormones gonadotropes sur la durée des processus spermatogénétiques chez le rat. Annls Biol. anim. Biochim. Biophys. 3, 329.

Go, V. L. W., Vernon, R. G. \& Fritz, I. B. (1971) Studies on spermatogenesis in rats. III. Effects of hormonal treatment on differentiation kinetics of the spermatogenic cycle in regressed hypophysectomized rats. Can. F. Biochem. 49, 768.

Hilscher, W. (1964) Beiträge zur Orthologie und Pathologie der Spermatogoniogenese der Ratte. Beitr. path. Anat. 130, 69.

Hollinger, M. A. \& Davis, J. R. (1969) Nucleic acid labelling of experimentally-induced cryptorchid rat testis. F. Reprod. Fert. 18, 325.

Lazar, P. \& Gerard-Marchant, R. (1965) Une technique de représentation graphique des numérations de grains sur autohistoradiographie. Annls Histochim. 10, 43.

Ortavant, R., Courot, M. \& de Reviers, M.M. (1969) Activités spécifiques des différentes FSH et LH sur le testicule des mammifères. In: La Spécificité Zoologique des Hormones Hypophysaires et Leurs Activités. Coll. Intern. C.N.R.S. no. 177, p. 369. C.N.R.S., Paris.

Roosen-Runge, E. G. \& Giesel, L. O. (1950) Quantitative studies on spermatogenesis in the albino rat. Am. F. Anat. 87, 1.

SMrTH, C. C. (1970) Investigations into the mechanism of action of a fish pituitary hormone. (Ph.D. no. 70-21-838.) Diss. Abs . 31, 2946.

Wiest, L. \& WRBA, H. (1970) Synthèse de DNA dans les spermatogonies des rats hypophysectomisés. Experientia, 26, 836. 